\title{
The use of "big data" in the organization of repair and construction works to ensure OTR
}

\author{
Nikolay Ivanov ${ }^{*}$ and Maksim Gnevanov \\ Moscow State University of Civil Engineering, Yaroslavskoe shosse, 26, Moscow, 129337, Russia
}

\begin{abstract}
Organization of work takes a significant place among the basic tasks of the construction industry. The organization of repair and construction works (R-CW) is especially important, since they have specific features in comparison with new construction. Today, information technologies are actively developing, which make significant changes in various industries, including construction. One of the progressive technologies today is the analysis of "big data". This article outlines the basic concept of using "big data" in the organization of R-CW, which makes it possible to increase the efficiency of organizational decisions, based on the characteristics of a particular repair and construction organization. The methodology proposed by the authors, aimed at the implementation of this concept, includes the solution of a number of tasks, such as assessing organizational decisions that are developed within the framework of a work production project, determining the level of organizational and technological reliability (OTR) and, as a consequence, choosing the best solution. As a tool for the implementation of the above tasks, the authors use a simulation model that makes it possible to simulate the process of performing repair and construction work, taking into account the random nature of their duration. The authors describe the experience of using the proposed methodology in the practice of functioning of one of the Russian construction organizations.
\end{abstract}

\section{Introduction}

Currently, the digitalization process is actively taking place, which has a significant impact on the spheres of human activity.

The digital economy is the activity of creating, distributing and using digital technologies and related products and services [1,2].

In the national program "Digital Economy of the Russian Federation" a number of "end-to-end" digital technologies are highlighted, which indicates a significant increase in digitalization. And, as a result, there is a growing need to apply new approaches and knowledge for the functioning of organizations in modern realities $[3,4]$.

The construction industry differs from a number of other organizational features, which entails an increase in the number of random factors that affect its functioning [5].

When a building is built and the process of its operation begins, then over time there is a need to carry out various kinds of R-CW, which may relate to current or major repairs, or to reconstruction. The same type of work can be performed in different ways using different

*Corresponding IvanovNA@mgsu.ru,makcg2009@gmail.com 
tools, which depends on a number of conditions and resources of the construction organization. An important task in the production of work is to ensure their timely completion $[6,7]$.

One of the actively developing and increasingly widespread use of technologies for collecting and processing significant arrays of heterogeneous information in the production of construction and repair and construction work is currently "big data". The term "big data" in a general sense implies technologies for collecting, processing and storing structured and unstructured information arrays characterized by a significant volume and rapid rate of change (including in real time) "[8-12]. Thanks to their use, it is possible to take into account the influence of various factors corresponding to one or another type of work and, as a result, it is possible to ensure organizational and technological reliability (OTR) when organizing a R-CW. By providing OTR, the authors of the article mean compliance with the terms and quality of work with limited resources available to a particular repair and construction organization [13, 14].

It is also important to note that the authors of the article do not focus on the volumes of data themselves, but on their heterogeneity and unstructuredness.

\section{Methodology}

The tasks of the methodology proposed by the authors are to assess the organizational decisions that are developed within the framework of the work production project, to determine the level of OTR and, as a consequence, to choose the best solution.

As a tool for the implementation of the above tasks, the authors use a simulation model that makes it possible to simulate the process of performing repair and construction work, taking into account the random nature of their duration.

The formula is taken as the basis for estimating the duration of each type of work

$$
t_{i}=\frac{V_{i^{*} Y_{i}}}{Q_{i}},
$$

where $t_{i}$ - duration i-th work, $\mathrm{i}$ - view R-CW, $Y_{i}$ - an indicator of the complexity of the i-th job, (person-day / unit units), $V_{i}$ - total amount of i-th work (unit of work), $Q_{i}-$ the amount of labor resource (people).

The basis for calculating the duration of the work is labor intensity, which is calculated according to regulatory documents. In reality, when performing work at a specific facility, the actual labor intensity may differ from the standard $[15,16]$. This can be caused by various factors, the impact of which can be predicted using the application of "big data". The author conducted a survey of a number of experts who identified a general list of factors that affect the labor intensity of performing certain types of R-CW.

In the course of the study, a survey was conducted of a number of specialists working in the construction industry, based on the results of which a list of factors was identified that affect the labor intensity of the R-CW (Table 1).

Table 1. Factors affecting the labor intensity of the R-CW.

\begin{tabular}{|c|c|c|}
\hline Factor number & Factor name & Designation \\
\hline 1 & Experience. & $\mathrm{X}_{1}$ \\
\hline 2 & Work experience. & $\mathrm{X}_{2}$ \\
\hline 3 & Constraint. & $\mathrm{X}_{3}$ \\
\hline 4 & Localization of the work front. & $\mathrm{X}_{4}$ \\
\hline 5 & Weather conditions & $\mathrm{X}_{5}$ \\
\hline 6 & Level of complexity of the & $\mathrm{X}_{6}$ \\
\hline
\end{tabular}




\begin{tabular}{|c|c|c|}
\hline & work. & \\
\hline 7 & Innovative technologies. & $\mathrm{X}_{7}$ \\
\hline
\end{tabular}

Different jobs can be influenced by different factors, and the degree of their influence can be different. Since the degree of influence of most of the factors was determined by the survey participants at a qualitative level, it is necessary to translate qualitative assessments into quantitative ones [17]. For this, the Harrington scale was applied. An example of a quantitative description of the factor of work experience is presented in Table 2.

Table 2. Work experience.

\begin{tabular}{|c|c|}
\hline Name & Value \\
\hline No experience (0 objects) & 1 \\
\hline Average experience - up to 3 years (3-5 objects) & 2 \\
\hline Work experience over 3 years (more than 5 objects) & 3 \\
\hline
\end{tabular}

Linear multiple regression was chosen as the main tool for working with "big data" to predict the complexity of R-CW implementation:

where

$$
Y_{i}=a_{0}+b_{1} a_{1} X_{1}+b_{2} a_{2} X_{2}+\cdots+b_{k} a_{k} X_{k}+\varepsilon_{i},
$$

$X_{1}, X_{2}, \ldots, X_{k}$ - parameters (factors) of regression dependence;

$a_{1}, a_{2}, \ldots, a_{k}$ - coefficients (weights) of parameters;

$b, b_{2}, \ldots, b_{k}$ - binary coefficient of significance of parameters for the i-th work ( 0 not significant factor, 1 - significant factor);

$\varepsilon_{i}$ - forecast error.

To determine the coefficients, it is necessary to have statistical data on the labor intensity of the work carried out in various cases by a specific repair and construction organization [18].

After the coefficients are calculated, it is possible to proceed to predicting the complexity of the R-CW. The $Y_{i}$ value is a random variable that obeys the normal distribution law, since there are a significant number of factors that affect the labor intensity in the process of performing R-CW [19].

The general structure of the stolen algorithm for providing OTR when organizing a R$\mathrm{CW}$ is shown in Figure 1. 


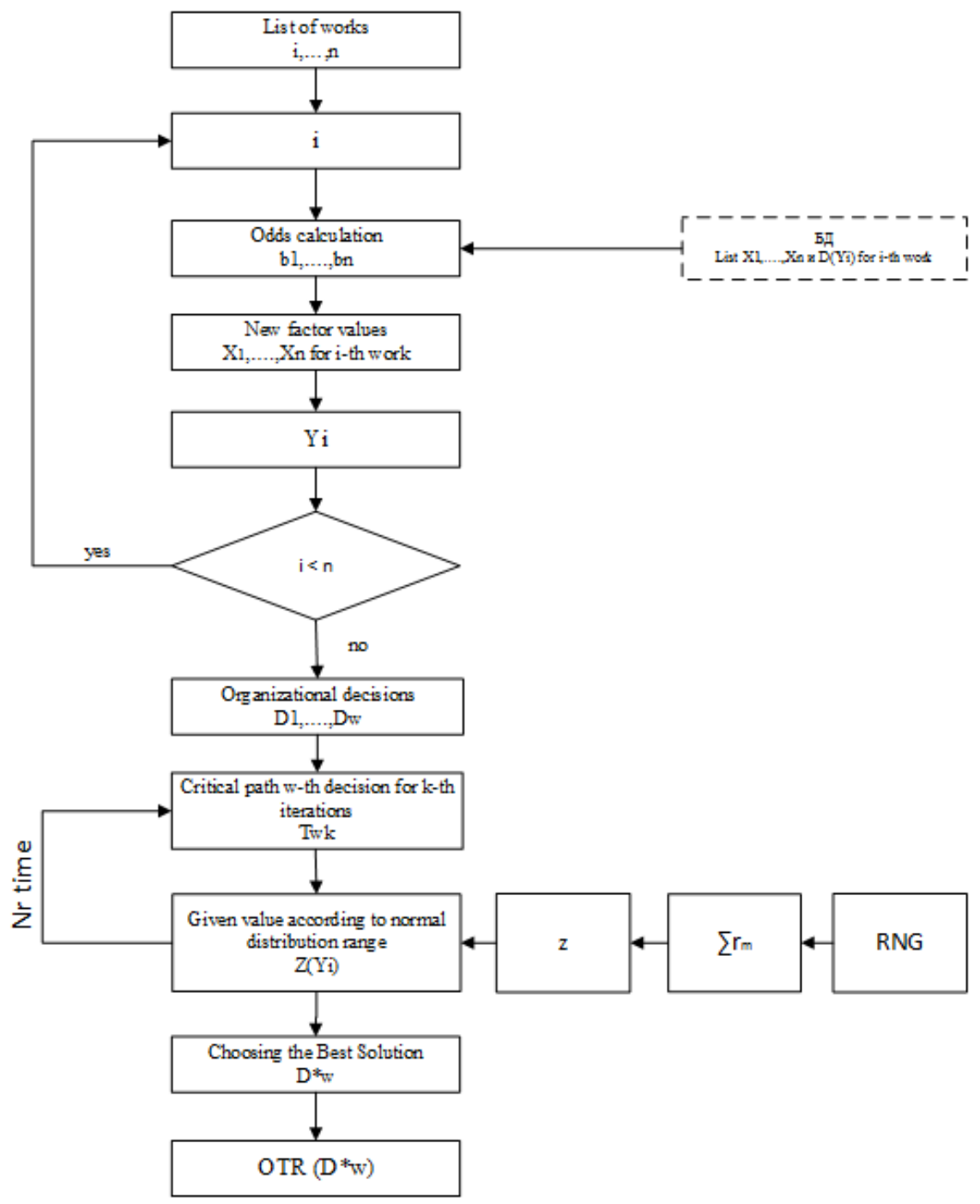

Fig. 1. An enlarged algorithm for providing OTR in the organization of R-CW.

The developed technique was applied in the organization "Baumetall" for organizing the $\mathrm{R}-\mathrm{CW}$ during the reconstruction of the facade of the building. In the process of organizing the R-CW, a calendar schedule was formed, presented in Figure 2. 


\begin{tabular}{|c|c|c|c|c|c|c|c|c|c|c|c|c|c|c|c|c|c|c|c|c|c|c|c|c|c|c|c|c|c|}
\hline & Month & & & & & & & & & & & & & & & & & & & & & & & & & & & & \\
\hline & Week & 1 & 2 & 3 & 4 & 5 & 6 & 7 & 8 & 9 & 10 & 11 & 12 & 9 & 10 & 11 & 12 & 13 & 14 & 15 & 16 & 17 & 18 & 19 & 20 & 21 & 22 & 23 & 24 \\
\hline 1 & Design of Ilegal armed groups & & & & & & & & & & & & & & & & & & & & & & & & & & & & \\
\hline 2 & \begin{tabular}{|l} 
Design of stained glass structures and \\
windows
\end{tabular} & & & & & & & & & & & & & & & & & & & & & & & & & & & & \\
\hline 3 & Installation / dismantiling of scaffididing & & & & & & & & & & & & & & & & & & & & & & & & & & & & \\
\hline 4 & Dismanting work & & & & & & & & & & & & & & & & & & & & & & & & & & & & \\
\hline 5 & $\begin{array}{l}\text { Instalalation of subconstruction and warming } \\
\text { of WFF }\end{array}$ & & & & & & & & & & & & & & & & & & & & & & & & & & & & \\
\hline 6 & Supply of terracotta facade slab & & & & & & & & & & & & & & & & & & & & & & & & & & & & \\
\hline 7 & Installation of a terracotta facade siab & & & & & & & & & & & & & & & & & & & & & & & & & & & & \\
\hline 8 & $\begin{array}{l}\text { Supply and manufacture of facade panels } \\
\text { made of aluminum composite }\end{array}$ & & & & & & & & & & & & & & & & & & & & & & & & & & & & \\
\hline 9 & $\begin{array}{l}\text { Instalation of facade panels from aluminum } \\
\text { composite, est. steel }\end{array}$ & & & & & & & & & & & & & & & & & & & & & & & & & & & & \\
\hline 10 & $\begin{array}{l}\text { Installation of parapet structures, lowres of } \\
\text { ots. Steel }\end{array}$ & & & & & & & & & & & & & & & & & & & & & & & & & & & & \\
\hline 11 & The arrangement of phs, aunings, porches & & & & & & & & & & & & & & & & & & & & & & & & & & & & \\
\hline 12 & $\begin{array}{l}\text { Production and supply of window and door } \\
\text { block designs }\end{array}$ & & & & & & & & & & & & & & & & & & & & & & & & & & & & \\
\hline 13 & Replacing existing window and dooc blocks & & & & & & & & & & & & & & & & & & & & & & & & & & & & \\
\hline 14 & \begin{tabular}{|l}
$\begin{array}{l}\text { Production and supply of structural glazing } \\
\text { designs }\end{array}$ \\
\end{tabular} & & & & & & & & & & & & & & & & & & & & & & & & & & & & \\
\hline 15 & 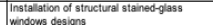 & & & & & & & & & & & & & & & & & & & & & & & & & & & & \\
\hline
\end{tabular}

Fig. 2. Linear work schedule.

Based on this graph, a network schedule was drawn up, presented in Figure 3.

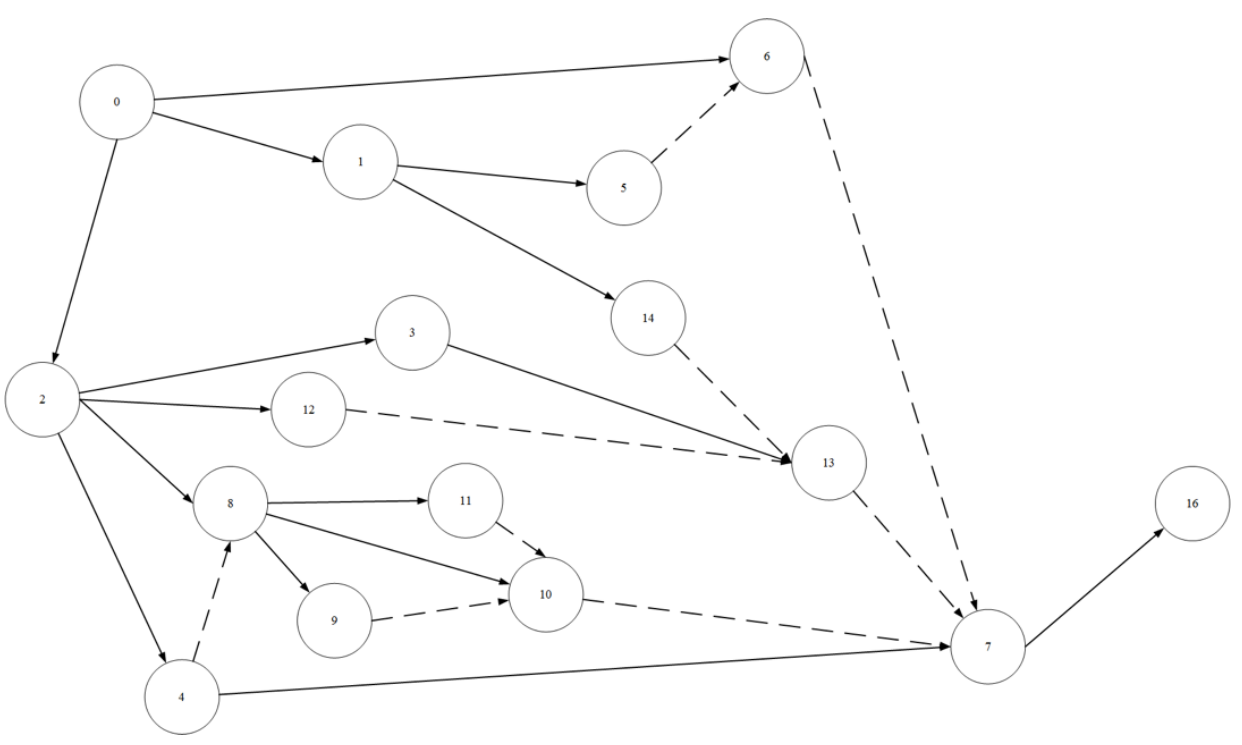

Fig. 3. Network schedule of work.

The key features of the organizational solution are:

- division of the building into seizures in the amount of 8 pieces;

- manual execution of dismantling works;

- production of mounting panels at the work site;

- manual device of pits, sheds, porches;

- piece delivery of window and door blocks.

The total estimated duration of the work was 101 days. At the planned time, the work will be completed in 104 days.

As a result of the application of the methodology, the OTR indicator of this organizational solution was $92 \%$, which indicates high reliability. 


\section{Results}

The presented practical application of the methodology based on the data of a specific repair and construction organization demonstrates its efficiency to ensure OTR in the organization of R-CW [20].

The use of "big data" can significantly improve the efficiency of organizational decisions, since it takes into account the data of a specific organization, which may differ from others. With long-term application of the methodology and an increase in the amount of statistical data, it is possible to draw conclusions about the level of reliability of organizational decisions with a high probability.

\section{Discussion}

Specific features of the construction industry show that the number of random factors that affect the performance of work is significant, which means that the result can differ significantly from the planned one.

Traditional approaches aimed at improving the efficiency of organizational solutions do not involve the mechanism of "big data" analysis. Therefore, when trying to improve the efficiency of organizational decisions, many factors are not taken into account that can have a significant impact on the performance of work at the facility.

The use of "big data" to improve the efficiency of organizational decisions allows you to form the most rational solution, the OTR indicator of which will indicate a high level of reliability.

\section{Conclusions}

Thus, the mechanism of "big data" in the organization of R-CW provides the choice of the most rational organizational solution, if there are several, or allows you to assess the level of OTR of any one developed solution. The use of "big data" makes it much easier to predict the timing of certain types of work, taking into account the influence of random factors on the complexity of their implementation. If necessary, it is possible to expand the methodology by supplementing it with a neural network mechanism, which in turn will improve the accuracy in determining the relationship between the value of the labor intensity of an individual work and the factors that influence it.

The developed methodology is the basis for the further effective functioning of repair and construction organizations, which makes it possible to provide OTR in the organization of repair and construction work even before their implementation.

\section{References}

1. Kulik L.V., Kravchenko E.V., Klejmyonova E. P. Academic Focus for Postgraduates. M.:, 56, (2021)

2. I. Marshev History of Management Thought. M.: Springer, (2021)

3. Bell D. The Coming of Post-Industrial Society. A Venture in Social Fore casting. Harmondsworth: Penguin Books, 507, (1973)

4. Michael J. Shaw E-Commerce and the Digital Economy. M.: Routledge, 304, (2006)

5. Davletkaliev R. What is Big Data, Part 2, https:// habrahabr.ru/post/308586/.

6. Ponyavina N.A. Povyshenie organizacionno-tekhnologicheskoj nadezhnosti remontnovosstanovitel'nyh i rekonstrukcionnyh rabot na ob"ektah nedvizhimosti: dissertaciya ... 
kandidata tekhnicheskih nauk: 05.02.22 / Ponyavina Nataliya Aleksandrovna; [Mesto zashchity: Voronezh. gos. arhitektur.-stroit. un-t]. Voronezh, 140, (2010)

7. Ginzburg A.V. Organizacionno - tekhnologicheskaya nadezhnost' stroitel'nyh sistem / A.V. Ginzburg // Vestnik MGSU, 251- 255, (2010)

8. Andreas, Myuller Vvedenie $\mathrm{v}$ mashinnoe obuchenie $\mathrm{s}$ pomoshch'yu Python. Rukovodstvo dlya specialistov po rabote s dannymi / Myuller Andreas. - M.: Al'fakniga, 487, (2017)

9. Das S. R. Big Data's Big Muscle // Finance \& Development, 3, 26-27, (2016)

10. Nezhnikova E.V. Problems of Reproduction of Environmentally Friendly Housing. Economics of Construction, 3 (45), 4-12 (2017)

11. Gurskaya E.D., Dotsenko M.A., Sokolyansky V.V. Big Data Technologies in the Service: New Markets, Opportunities and Problems. Issues in Economic Sciences, 4(74), 42-44 (2015)

12. T. Jordan Big Data in Practice: How 45 Successful Companies Used Big Data Analytics to Deliver Extraordinary Results. M.: Wiley, 320, (2016)

13. Maltseva S.V., Lazarev V.V. Marketing analytics in the field of electronic business on the basis of large data. Information technologies in design and production, 62-67, (2015)

14. Ivanova M.A., Ginzburg A.V. Vzaimosvyaz' kachestva organizacii maloetazhnogo stroitel'stva i organizacionno-tekhnologicheskoj nadezhnosti stroitel'nogo proizvodstva // Nauka i biznes: puti razvitiya, 9(87), 33-37, (2018)

15. Domingos, P. Verhovnyj algoritm. Kak mashinnoe obuchenie izmenit nash mir / P. Domingos. - M.: Mann, Ivanov i Ferber, 656, (2016)

16. Ivanov N.A., Gnevanov M.V. Ocenka sostoyaniya zdanij pered remontnymi rabotami na osnove primeneniya tekhnologij mashinnogo obucheniya // Perspektivy nauki, 4(94), 46-48, (2019)

17. Torgo L., Ribeiro R.P., Pfahringer B., Branco P. SMOTE for Regression. Progress in Artificial Intelligence, EPIA, 378-389, (2013)

18. Das S. R. Big Data's Big Muscle. Finance \&amp; Development, 3(26-270), (2016)

19. Kitchin, R. The Data Revolution: Big Data, Open Data, Data Infrastructures and Their Consequences. Sage, 722-723 (2014)

20. Ivanov N.A., Gnevanov M.V. Big Data: Perspectives of Using in Urban Planning and Management // MATEC Web of Conferences, 170, (2018) 